UDC 37.01

\author{
N.A. Lukianova, E.V. Fell, O.A. Skalnaya
}

\title{
CAREER CONSTRUCTION: INCLUSIVE EDUCATION FROM SCHOOL TO COLLEGE AND UNIVERSITY
}

\begin{abstract}
This article presents the obstacles that Russian schoolchildren with special needs face when considering vocational and professional education. Using the analysis of official reports, applied research methods and sociological methods, the researchers identified the following obstacles: lack of specific career guidance at school; disabled students' fear that they lack physical strength to study and the negative attitude of others.

Keywords: children with special needs; employment of disabled people; career development; Russian education; physical fitness; physical rehabilitation; inclusive education.
\end{abstract}

Introduction. The acquisition of education (of all levels) is currently the main component of the policy of inclusion and a key tool for the social adaptation of children with special needs which should enable them to gain economic independence in the future (The research was supported by the Russian Science Foundation (grant No. 1618-00016). In this process, career planning is seen as a constant component, despite the fact that the individual trajectory of one's career may change throughout one's life and constantly evolves. The construction of a career depends both on the way individuals approach this issue in order to find solutions, and on the way they perceive reality. In particular, the success of career development at least partially depends on an individual's ability to adapt to their environment, and not on the person's maturity [1. P. 239]. Savickas' paradigm for career construction involves the construction of the process through small stories of victories and design intentions, adaptive technologies and programs. Consequently, creating conditions for the adaptation of children with special needs to learning and social environment is an important task of inclusive education, as it should help them in their professional orientation.

Research aim: to analyze obstacles that prevent children with disabilities from entering a college or university; to understand how these obstacles can be removed through social and physical adaptation programs at a school, college or university; to present the principles for the development of these programs in accordance with the key principles of inclusion.

The object of the study: discussion of obstacles that children with disabilities encounter during the transition from secondary education (school) to professional and vocational education (college, university).

The results of the research indicate that children with special needs experience not only difficulties in entering a college or university and following the program of study. They are also concerned about various issues associated with the learning process such as fatigue, lack of strength [2], physical access to infrastructure, negative attitude of others [3-5].

Conceptual framework. This study emphasizes that disabled people's visible participation in social processes is seen as the criterion of the realization of equal opportunities [6]. The authors draw on the following principles for building the working life of people, models of career support - "constructing of a career" following M.L. Savickas, L. Nota, J. Rossier: 1) accounting for op- portunities in accordance with current circumstances ("contextual" element); 2) dynamic (not static) monitoring and supporting process; 3 ) expecting to make some progress at each stage; 4) considering and comparing many perspectives; 5) modeling individual trajectories [1].

The authors also take into account extensive existing research on methods of career support, counseling and vocational guidance: studies of specialists from recognized centers of career construction research in France (Paris), Switzerland (Lausanne), Italy (Padua), USA (Ohio), Portugal (Lisbon), Belgium (Brussels), Holland (Amsterdam) [Ibid.].

In the theory of career construction, the key element is the model of reasoning, which a person with disabilities adopts as a model of his or her professional behavior, which is realized during his or her life cycle. The authors report on the research findings, which suggest that activities aimed at developing communication skills and physical training in preparation for study in higher education are amongst the most effective inclusion mechanisms. This is seen as the main task of programs for the adaptation of schoolchildren to studying in the system of professional and vocational education, to the transition from school to college (university).

Research methods. In order to present the current research findings in the framework of existing body of knowledge, the authors accessed official statistics presented on official websites and information resources associated with disability issues in Russia.

In Russia, there were several studies on the problem of disabled people in the system of higher education since the 90 's. For example, in 2002-2003, a group of sociologists of Saratov State Technical University with the support of the Ford Foundation and the Independent Institute of Social Policy (E.V. Belozerova, D.V. Zaitsev, G.G. Karpova, E.K. Naberushkina， P.V. Romanov，A.A. Chernetskaya, E.R. Yarskaya-Smirnova (principal investigator) conducted a study titled "Accessibility of Higher Education for Disabled People" [7-9] (Leading organization: Center for Social Policy and Gender Studies).

In 2002-2004, a team of researchers carried out the project titled "Analysis of Accessibility of Higher Education for Socially Vulnerable Groups", and its research findings were published in the collection of articles of the Independent Institute for Social Policy [10]. The articles contain information on the differences in the opportunities for higher education access for different social groups, including children with disabilities. 
In April-June 2008, a large-scale sociological study of the problems of disability and rehabilitation of disabled people was carried out within the framework of the project "System of Rehabilitation Services for People with Disabilities in the Russian Federation" (Kostroma, Moscow, Saratov regions and St. Petersburg). The project of this scale and scope was conducted for the first time in Russia. It involved a large number of Russian and European experts, renowned specialists in sociology, rehabilitation and social policy, from Oxford and Exeter Universities (Great Britain), St. Petersburg State University, and Moscow Institute of Medical and Social Rehabilitation, Center for Social Policy and Gender Studies (Saratov, Russia). In the course of the study, researchers obtained data that present a real assessment of the situation of disabled people in the Russian Federation. It contributed to the improvement of the state social policy with regard to disabled people and provided grounds for working out concrete measures aimed at increasing the effectiveness of integrated rehabilitation and social integration of disabled people. This research made it possible to determine the parameters of teachers' readiness to accept students with disabilities and able-bodied students' readiness to accept disabled peers. Moreover, it was possible to evaluate the existing level of development of the environment accessibility and consider the range of professions, which people with disabilities mostly choose to pursue, and also the measures by means of which universities create opportunities for disabled people's access to higher education [11].

This article introduces the project titled "Physical, Social, and Psychological Adaptation of Children with Disabilities to Vocational Training" conducted at Tomsk Polytechnic University (Russia). The researchers used an interdisciplinary approach as a research strategy - this makes such a project unique. Colleagues of the Department of Physical Culture (principal investigator Professor L. Kapilevich) examined the specificity of motor movement of 100 Tomsk schoolchildren of 8th, 9th and 10th grades with various forms of disability (mainly with cerebral palsy). This allowed Kapilevich's research team to assess the overall motor processes of students' locomotion. During the assessment, the electronic platform registered at what angle a person makes a step, special sensors evaluated the movements of his or her arms and legs, traced the pattern of imbalance, the electrodes fixed the work of the muscles and the ways of walking. For this study, children with significant but not critical disorders were selected and included those who had impairments of the motor apparatus and severely impaired vision.

Simultaneously, researchers from the department of Social Communications of Tomsk Polytechnic University (principal investigator Professor N. Lukianova) conducted a survey of these schoolchildren's views on inclusive education. Their parents and experts in the field of inclusive education were also included in the study. The first study was conducted as a formalized questionnaire survey of Tomsk secondary school students (9th-11th grades) with disabilities. This was a mass survey of the social community of Tomsk schoolchildren, who have various disabilities.

As part of the second study, which was conducted simultaneously with the first one, children's parents (guardians) were also interviewed using formalized questionnaires, correlating on their questions with the questionnaires for children. A total of 70 observation units were analyzed. Of these, $39 \%$ were girls and $61 \%$ were boys. The second study involved 60 parents of disabled children. Of these, $94.8 \%$ were parents of children with disabilities, 2 guardians (3.4\%) and one respondent $(1.7 \%)$ was "another relative". The purpose of the study of the first two surveys was to understand how children planned to continue their education and what the main obstacle in planning their professional career (in the process of choosing a college or university) was. The researchers also set a task to analyze what the reason for the refusal to pursue professional education was and what future obstacles those who are ready to become a student, envisage in the future.

The third study involved questioning experts - teachers, organizers of the educational process, education psychologists, whose work is directly connected with the teaching of students with disabilities in the system of inclusive vocational and professional education. A total of 34 experts (38\% men and 62\% women) took part in the survey. Seventeen people work as teachers directly with students with disabilities. All the data were analyzed within the framework of the contextual approach, based on Savikas' theory of professional career development. The theory describes cognitive and interpersonal processes that give meaning and direction to individual professional choice [12]. The researchers also studied official reports containing information about the problems which people with disabilities face when pursuing professional education and later on when building a career.

Results of the study. The analysis of the obstacles that children with special needs from the upper grades and their parents see on the way to vocational and professional education in the course of the transition from school to college or university, allowed the research teams to conclude the following.

1. The study conducted by Professor Kapilevich's research group revealed a clear relationship between the level of confidence in children's motor movement and the level of confidence in social communication. Studies of the physical abilities of schoolchildren revealed that children with the same diagnosis and health condition can significantly differ in their level of adaptation to social reality. Whilst one child can move independently and is not afraid to go for a walk with his or her peers, another child considers himself or herself disabled and prefers to stay at home. Consequently, the former is ready to continue his or her professional education, as he or she has a positive experience of social communication, and the latter fears to consider further and higher education options.

2. Sociological studies demonstrate that disabled children's social communication skills and the level of career guidance they receive depend largely on the parents. Students with disabilities were asked how they obtained information about professional and vocational education. Respondents were not limited in the number of selected answers, and the hierarchy of answers looked like this (the answers ranged from the ones that received the largest number of selections to the lowest): "From parents" $61 \%$; "I independently search the Internet" $-60 \%$; "From 
friends, classmates" - 36\%; "From social workers" $10 \%$. According to the spread of the responses, both parents and school help children with disabilities to determine their professional choices. Children themselves are also proactive in finding information. However, the responses also reveal that there is a lack of information in understanding what their career can be specifically. This can be explained by the fact that career guidance in schools is aimed at able-bodied children - the majority.

Our respondents study in mainstream classes and they need the filtering of the information flow presented to potential applicants. When asked whether they are sufficiently informed about the professional education no respondents selected the answers "I do not need information" or "There is absolutely no information". The largest percentage of respondents answered "yes, quite" 49\%; "I already know a lot, but I would like even more" $31 \%$ and $20 \%$ chose the answer "I have very little information on what kind of professional education I could get". The respondents were obviously interested in receiving information about opportunities for obtaining a professional education, but at least $51 \%$ of this need was not fulfilled. As emphasized in the study conducted at the Monitoring Laboratory of Moscow City Psychological and Pedagogical University, "Weak awareness of inclusive education remains a major barrier to its implementation" [13].

Young people's evident orientation to continue vocational and professional education is partly the result of their parents' influence. $27.6 \%$ of parents reported that their children were going to pursue a course in secondary vocational education, $70.7 \%$ of parents reported that their children were going to pursue a course in higher education, $1.7 \%$ responded that the child had not yet made his or her decision. When asked who made the decision regarding further education plans, the majority (76\%) said that the decision was made jointly; $21 \%$ of parents responded that this was primarily the decision of the child himself or herself, and 3\% responded that the child considered the parents' opinion.

3. Another issue concerned various barriers to vocational and professional education. The question was "What do you think, for people with health restrictions, what can be the most difficult in obtaining a professional education? (Choose the most important obstacles and no more than 3). Respondents could choose the following answers: "I do not see any special difficulties"; "Fatigue, lack of strength"; "It is physically very difficult to get to the place of study"; "Negative attitude of others".

The following results were obtained. If we talk in general about the entire group of respondents (regardless of nosology), the greatest difficulty for them was "fatigue, lack of energy" - 67\%. The second most popular answer was "I do not see any special difficulties" $-37 \%$ and "the negative attitude of others" (31\%) was the third. Undoubtedly, there were differences in responses depending on the nosology and severity of the child's condition. In general, parents see the same obstacles in obtaining a vocational and professional education as their children. The three leading answers were as follows. The greatest difficulty for both parents and their children was "fatigue, lack of strength" $-53 \%$. The second most popular answer for both groups was "I do not see any special difficulties" $41 \%$, but financial difficulties was the third answer as far as parents were concerned (36\%) and "negative attitude of others" in the children's responses $(31 \%)$.

Here we return to the problem, which was mentioned in connection with the first result of the study. Fatigue, lack of energy is a major obstacle standing in the way of the acquisition of professional and vocational education. This can be considered the first obstacle in the construction of a career. Sociological research confirms the conclusion that in matters of designing a career for children with special needs, more attention should be given to physical training. This is an important factor that affects the child's prospects of future professional education, and the parents' attitude is important here.

The researchers found consequential differences in parents' approach to their children's physical adaptation to the environment. One child could be taken everywhere with parents, taught to move independently, encouraged not to be afraid of difficulties, to communicate with his or her classmates, even if he or she does not play active games with them. Another child with the same diagnosis could be fully cared for by his or her parents, not allowed to go out, with the parents taking care of his or her health to the point of overdoing it.

In Russia, very few researchers link psychomotor disorders and the specific features of the social organization of life. R.V. Rogova stresses that the motor-muscle sensations form the basis of cognition of the surrounding reality [14]. V.S. Dmitriev asserts that motor skills training and improving stamina constitute one of the components of a socially significant future result, including hopes, attitudes and activities - flexible adjustment to the real capabilities of the individual [15].

Communication theorist N. Bar-Am [16] links communication with physical orientation in an environment and adaptation to it and argues that people's spatial positions - and movements - in relation to one another and to the societal whole affect and determine the nature of their situational communication. A confidently moving person will feel confident about communicating with others and will be more willing to integrate into peer groups. Thus, it could be suggested that it is necessary to include elements of physical adaptation into career construction programs as the latter has an integrative social function.

The second barrier standing in the way of the process of obtaining professional and vocational education was this: "It is physically very difficult to get to school" as indicated by our respondents. At present, in the Russian Federation, only 10 percent of universities provide not only architectural but, first and foremost, educational and methodological accessibility of higher education for disabled students, demonstrating a proper level of professional and pedagogical competence of the teaching staff.

Not surprisingly, these higher educational institutions become centers of attraction for disabled young people and accumulate the largest number of disabled students. In addition, in Russia, only 21 universities, according to monitoring, have the opportunity to train people with disabilities of any nosology [17]. At present, a network of resource (support) centers in federal districts is being created in Russia on the basis of higher education institu- 
tions, which have considerable experience of working with students with disabilities of various nosologies. These local centers are coordinated from a single center. Since not all universities can create a comprehensive system of inclusion because of limited funding, such a network is supposed to solve accessibility problems in the higher education system.

The researchers note that the significance of a given barrier preventing inclusion depends not only on objective reasons (for example, such as the inability to move around the city in a wheelchair) but also on the subjective attitudes of the person with a disability, which was mentioned earlier. In this respect, the research team concluded that adaptation and career design programs should include a set of physical exercises that will not only improve the person's physical condition, but also help the student gain greater confidence in himself or herself.

It has also been suggested that the solution to the issue of physical accessibility of educational facilities can be partly solved through the project collaboration that involves various groups of students. Moreover, the overcoming of this barrier would be closely connected with the overcoming of another barrier, indicated by our respondents as the third most important obstacle - the negative, hostile attitude of others. As was mentioned earlier, this was the third most popular answer as $31 \%$ of respondents answered like this. Romanov and YarskayaSmirnova [8] emphasize that barriers are not in themselves specific features of someone's appearance, communication or movement patterns, but are results of the lack of public participation, which exacerbate social inequality between people. The authors of the article argue that one of the ways to overcome the first and second barriers could be the involvement of team project work of school and university students.

In line with this suggestion, Lukianova directed a project in autumn 2016, at Tomsk Polytechnic University whereby a team of students studying industrial design completed a portfolio consisting of the results of monitoring and assessment of the level of accessibility of the architectural environment on campus for students with disabilities. The portfolio included an interactive map of the campus.

The main objectives of this team student project were formulated as follows. Students had to analyze official documents that define norms and rules for assessing accessibility and regulate legal relations in the area of research. Moreover, they had to develop methodological recommendations for assessing the state of accessibility of a user-friendly social environment inside the campus and identify barriers to accessibility on campus for people with disabilities specifically including students with disabilities.

Thirteen objects (educational buildings) were chosen for the project. The students had to survey areas around the buildings in order to assess their accessibility and to identify the most convenient routes between buildings that have auditoriums adapted for the use by students with disabilities. The complexity of the project was due to the fact that the Tomsk Polytechnic University campus is spread across the city; therefore, the university may not always independently remove barriers that stand in the way of someone moving from one university building to another. The students, under the guidance of certified experts in assessing the accessibility of the architectural environment (teachers of the Department of Industrial Design V.Y. Radchenko and E.M. Davydova), conducted the necessary measurements, took photographs. The work was carried out with the direct participation of students with disabilities (wheelchair users and visually impaired people), as mixed working groups were formed [18].

On the one hand, this approach allowed future engineers to see the existing problems for students with disabilities in real life as part of their learning process; on the other, joint work on a team student project was an effective tool for integrating students with disabilities into the process of education.

Drawing on the experience of implementing this student project, the researchers involved in the project argue that such a barrier as the negative attitude towards disabled people is not presented as obvious hostility or aggression. The researchers interpret this problem in two ways. As far as they are concerned, on the one hand, the problem lies in the way society perceives disabled people.

For example, an article describing this project refers to the following real life situation: "While a person on crutches is struggling to get out of the bus, half of the passengers prefer to turn away demonstratively and the other half rushes to help no less demonstratively. Meanwhile, both approaches are incorrect, as they force people with disabilities to feel uncomfortable, as a result of which many of them prefer not to leave their apartment if they can help it" [19].

So, the first position reflects the way able-bodied people view disabled members of society. Here are the results of a sociological survey (2015), which correlates with the research of our working group, as it examined the way young people under 25 perceive wheelchair users in society. The results of the study are described in the article by M.V. Shimolina [20]. Anonymous questioning and interviews were chosen as research methods. The questionnaires consisted of 25 questions. A total of 122 students were interviewed, with 62 respondents representing humanitarian courses and 60 students representing technical courses.

The results concerning the question of whether young people feel uncomfortable when meeting wheelchair users were encouraging: $36.8 \%$ answered that they did not feel uncomfortable when meeting with wheelchair users; $49 \%$ answered 'sometimes' and only $13.9 \%$ responded affirmatively. This makes the researchers suggest that an increasing number of young people in Russia accept wheelchair users as members of society. The author of the article concludes that "the prevailing percentage of young people fully supports the activity of wheelchair users in the society as it [activity] has been gaining momentum over the past five years" [20].

It is worth noting that the perception of disability largely depends on public policy, on how often images that emphasize equal (not special) position of disabled people appear on television, in advertising and so on. For example, a positive attitude in society towards people with disabilities appeared after watching the television series "Ironside" (1967-1975), where Raymond Burr 
played the role of a detective in a wheelchair. The viewers of the series noted that they did not notice the "disability" of the protagonist because it had no significance in the narrative [21].

On the other hand, researchers note that the perception of disability in society is a two-way process. It can consist of discriminatory and/or negative emotional reactions to the presence of a disabled person (curiosity, mockery, awkwardness, guilt, excessive care, fear, etc.) combined with the frustrating emotions of the disabled person (selfpity, negative feelings towards others, the desire to blame someone else for their disability, desire for isolation). This combination prevents people with disabilities from integrating into a wider society. Today, Russian society is actively working to change this situation. These efforts include e.g. the creation of social advertising in the series "The City of Equal Opportunities" and the films "Love with Restrictions" (2016), documentaries etc.

Following the research findings described earlier, we presented three main barriers that the respondents identified, answering the question about their vision of their professional future: fear of fatigue and lack of strength; lack of physical accessibility of the infrastructure and fear of other people's negative attitude. As the research findings indicate, all three barriers are closely related and the work towards removing them requires career support programs involving multiple approaches to concrete situations.

It is important to draw on existing achievements as in many developed countries methods of career support which involve counseling and career guidance have already been developed in accordance with the five principles of career support model (see above).

Social inclusion programs are being introduced both in old and new member countries of the European Union, and they are subject to mutual evaluation by experts from at least six countries. Among the programs that are being assessed, there are those that are aimed at people with disabilities, migrants, ethnic minorities, socially vulnerable groups of women and children, as they focus on employment, social services, health care, and education.

The inclusion programs, aimed at achieving tangible effects, focus mainly on promoting active social inclusion understood as the participation of different stakeholders in diverse social processes. The creation of such programs seems relevant and effective and in principle could be adapted for use in the Russian Federation, provided that it is created and supervised by working groups of independent experts with appropriate qualifications.

It can be argued that adaptation programs focusing on the transition from general education to professional and vocational education should take into account that disability is the result of the interaction between people and the environment in which they live [22].

The ultimate goal of our ongoing research is to define parameters for a theoretical foundation, which can be used to create effective government policies, aimed at facilitating and regulating inclusive education in further and higher education institutions.

Following the newly developed Manifesto for Inclusion (www.unipd.it/counseling-and-support2017/en/ mani-festo), which promotes the renewed sense of social responsibility towards vulnerable citizens, we suggest that the work towards removing barriers preventing inclusion in education should involve the following principles: awareness of concrete inequalities and inadequacies in educational processes and willingness to promote more inclusive conditions; openly promoting and publicizing various stakeholders' commitments to inclusion which are relevant in their daily work context; monitoring results that have been achieved in the course of following the realization of one's expressed commitments.

\section{REFERENCES}

1. Savickas. M.L., Nota, L. \& Rossier, J. (2009) Life designing: A paradigm for career construction in the 21 st century. Journal of Vocational Behavior. 75. pp. 239-250. DOI: 10.1016/j.jvb.2009.04.004

2. Pizzi, J. (2008) Challenges of children with physical disabilities. Rivier Academic Journal. 4(1). [Online] Available from: https://www.rivier.edu/journal/ROAJ-Spring-2008/J149-Pizzi.pdf.

3. Kim, S. (2005) Kevin: "I gotta get to the market": The development of peer relationships in exclusive early childhood settings. Early Childhood Education Journal. 33(3). pp. 163-169. DOI: 10.1007/s10643-005-0041-3

4. Eriksson, L., Granlund, M., \& Welunder, J. (2007) Participation in everyday school activities for children with and without disabilities. Journal of Developmental and Physical Disabilities. 19(5). pp. 485-502. DOI: 10.1007/s10882-007-9065-5

5. Rogers, A., Smith, R. \& Lieberman, A. (2006) Human Behavior in the Social Environment. Boston: McGraw-Hill.

6. Terzi, L. (2010) Justice and Equality in Education: A Capability Perspective on Disability and Special Educational Needs. London: Continuum.

7. Yarskaya-Smirnova, E.R. \& Romanov, P.V. (2005) Accessibility of higher education for disabled. [Online] Available from: http://ecsocman.hse.ru/data/456/846/1217/89-99.pdf. (In Russian).

8. Romanov, P.V. \& Yarskaya-Smirnova E.R. (2010) Disabled persons and society: twenty years later. Sotsis - Sociological Studies. 9. pp. 50-58. [Online] Available from: http://demoscope.ru/weekly/2011/0463/analit02.php. (In Russian).

9. Yarskaya-Smirnova, E.R. \& Romanov, P.V. (2009) Obrazy invalidov v massovoy kul'ture [Images of disabled people in mass culture]. Sistema reabilitatsionnykh uslug dlya lyudey s ogranichennymi vozmozhnostyami v Rossiyskoy Federatsii. 5. pp. 4-12.

10. Shishkin, S.V. (ed.) (2004) Dostupnost' vysshego obrazovaniyav Rossii [Accessibility of higher education in Russia]. Moscow: Independent Institute for Social Policy. [Online] Available from: http://www.socpol.ru/publications/pdf/dvo.pdf.

11. Mterentiev.ru. (2008) Press-conference presenting the project "A System of Rehabilitation Services for People with Disabilities in the Russian Federation. [Online] Available from: http://www.mterentiev.ru/news/news.php?id=264. (In Russian).

12. Brown, S.D. \& Lent R.W. (2005) Career development and counseling. Putting theory and research to work. New York: Wiley.

13. Sobolevskaya, O.V. (2013) Vysshee obrazovanie na puti $k$ bezbar'ernoy srede [Higher education on the way to a barrier-free environment]. [Online] Available from: https://iq.hse.ru/news/177670553.html. (In Russian).

14. Rogova, R.V. (2015) Physical rehabilitation and social adaptation of persons with limited sensory capabilities. Pedagogiko-psikhologicheskie $i$ mediko-biologicheskie problemy fizicheskoy kul'tury i sporta. 2(15). pp. 93-98. (In Russian).

15. Dmitriev, V.S. (2003) Adaptivnaya fizicheskaya reabilitatsiya v soderzhatel'nom, strukturnom i organizatsionnom aspektakh [Adaptive physical rehabilitation in informative, structural, and organizational aspects]. Vestnik sportivnoy nauki-Sports Science Bulletin. pp. 39-41.

16. Bar-Am, N. (2016) In Search of a Simple Introduction to Communication. Springer International Publishing. 
17. RIA.ru. (2011) Top vuzov po dostupnosti zdaniy dlya malomobil'nykh grupp naseleniya [The top universities on accessibility of buildings for groups of population with low mobility]. [Online] Available from: http://ria.ru/ratings_analytics/20110711/400106487.html.

18. Tomsk Polytechnic University. (2016) Dostupnaya sreda [Accessible environment]. [Online] Available from: http://evvec7.wixsite.com/sredatpu.

19. Kolesova, O. (2016) Zhizn' bez isklyucheniya. V TPU sozdayut blagopriyatnuyu sredu dlya studentov s ogranichennymi vozmozhnostyami. [A life without exceptions. In TPU favorable environment for the students with disabilities has been created]. [Online] Available from: http://www.poisknews.ru/theme/science/21087/.

20. Shimolina, M.V (2015) Perception of wheelchair users by young people in society: the results of the survey in Khabarovsk. Sovremennye issledovaniya sotsial'nykh problem. 11 (55). pp. 35-45. (In Russian).

21. Morris, J. (1991) Pride Against Prejudice: Transformation Attitudes to Disability. London: Women's Press.

22. Nota, L. et al. (2015) Inclusion in Italy: From numbers to ideas . . that is from "special" visions to the promotion of inclusion for all persons. Life Span and Disability. XVI:2. pp. 187-217.

\section{CAREER CONSTRUCTION: INCLUSIVE EDUCATION FROM SCHOOL TO COLLEGE AND UNIVERSITY}

Vestnik Tomskogo gosudarstvennogo universiteta - Tomsk State University Journal, 2018, 432, 51-56. DOI: $10.17223 / 15617793 / 432 / 6$

Natalia A. Lukianova, Tomsk State University (Tomsk, Russian Federation); Tomsk Polytechnic University (Tomsk, Russian Federation). E-mail: kir712@mail.ru

Elena V. Fell, Tomsk Polytechnic University (Tomsk, Russian Federation). E-mail: elena.fell@ntlworld.com

Oksana A. Skalnaya, Tomsk State University (Tomsk, Russian Federation). E-mail: tairus14@gmail.com

Keywords: children with special needs; employment of disabled people; career development; Russian; education; physical fitness; physical rehabilitation; inclusive education.

Received: 08 April 2018

\section{КОНСТРУИРОВАНИЕ КАРЬЕРЫ: ИНКЛЮЗИВНОЕ ОБРАЗОВАНИЕ ОТ ШКОЛЫ К КОЛЛЕДЖУ И УНИВЕР- СИТЕТУ}

Вестник Томского государственного университета. 2018. 432. 51-56. DOI: 10.17223/15617793/432/6

Наталья А. Лукьянова, Томский государственный университет, Томский политехнический университет (Томск, Россия). E-mail: kir712@mail.ru

Елена В. Фелл, Томский политехнический университет (Томск, Россия). E-mail: elena.fell@ntlworld.com

Оксана А. Скальная, Томский государственный университет (Томск, Россия). E-mail: tairus14@gmail.com

Ключевые слова: дети с особыми потребностями; трудоустройство инвалидов; развитие карьеры; образование в России; физическая подготовка; физическая реабилитация; инклюзивное образование.

Изучаемая проблема связана с одной из социальных задач государственной политики - занятости инвалидов, их способности строить карьеру в соответствии с выбранной профессией и приобретенными знаниями. В данном исследовании определены и проанализированы препятствия, с которыми российские дети с особыми потребностями сталкиваются в старших классах школы, а также то, как родители таких детей видят их перспективы в получении профессионального образования. Концептуальная основа исследования заключается в рассмотрении проблемы инвалидности с точки зрения участия в социальных процессах как поля для реализации равных возможностей. Методы исследования, используемые в статье, включают анализ официальных отчетов, содержащих информацию о проблемах, с которыми сталкиваются дети с особыми потребностями при получении профессионального образования, а затем при создании карьеры. Прикладные методы исследования, упомянутые в исследовании, включают метод компьютерной стабилографии для пространственного и временного анализа состояния равновесия, позволяющий оценить уровень физической подготовки детей с особыми потребностями. Социологические методы включают опрос школьников и их родителей и опрос экспертов в области инклюзивного образования.

В процессе проведения исследований получены следующие важные результаты. Первым препятствием в процессе построения карьеры является то, что профориентация в школах нацелена на преобладающую группу школьников - здоровых детей. Наши респонденты учатся в обычных классах, но им необходимо предложить информацию, подходящую для их потенциальной профессии. Вторая причина, которая препятствует развитию карьеры, - это страх, что они не смогут физически продолжить учебу. Поэтому в статье утверждается, что физическая реабилитация должна сопровождать процессом обучения в непрерывном режиме (85\%), поскольку адаптивная физическая культура очень полезна в процессе физической реабилитации и способствует повышению качества самого образования. Третья причина, которая мешает планированию карьеры, - негативное отношение окружающих. Результаты исследования могут быть использованы при формировании государственной политики в области инклюзивного образования. Официальная статистика показывает, что из тех инвалидов, которые приходят в средние специальные и высшие учебные заведения в России, в лучшем случае $50 \%$ и даже меньше заканчивают учебу. 